$$
\begin{array}{ll}
\text { Volume } & : 05 \\
\text { Nomor } & : 03 \\
\text { Bulan } & : \text { September } \\
\text { Tahun } & : 2019 \\
\text { http } & : \text { //ejurnal.pps.ung.ac.id/index.php/AKSARA/index }
\end{array}
$$

\title{
PENDIDIKAN MASYARAKAT PADA PERTUNJUKAN TURUNANI DALAM UPACARA ADAT GORONTALO
}

\author{
La Ode Karlan, Abdul Rahmat, Mira Mirnawati \\ Universitas Negeri Gorontalo \\ laodekarlan@gmail.com
}

Received: 02 Juni 2019; Revised: 19 Juli 2019; Accepted: 25 Agustus 2019

\begin{abstract}
ABSTRAK
Turunani yang dihadirkan dalam berbagai upacara adat peralihan masyarakat Desa Kramat, Kecamatan Tapa, memiliki perbedaan dari aspek kebentukannya, seperti: pada upacara adat aqiqah, khitanan, dan pernikahan. Sehingga muncul pertanyaan bagaimana bentuk pertunjukan turunani dalam berbagai upacara adat peralihan tersebut, dan alasan-alasan apa saja sehingga turunani dapat dihadirkan dalam upacara adat tersebut. Sehingga, dalam penelitian ini ditemukan bentuk secara musikal seperti teknik permainan pola tabuhan 3, 7, dan 9 yang digunakan pada prosesi upacara adat dalam konteks tertentu, dengan lantunan syair yang bermakna pembinaan moral, pembentukan ahlak, dan peningkatan kualitas keimanan dan ketaqwaan kepada Allah SWT, melalui sanjungan dan puji-pujian kepada Nabi Muhammad SAW menurut ajaran agama islam, sehingga menjadi pegangan hidup yang kokoh bagi masyarakat khususnya di Desa Kramat. Dengan demikian, terkait dengan maksud-maksud tersebut, maka fungsi turunani ditemukan 4 fungsi yang melingkupi kehadirannya dalam berbagai upacara adat peralihan yakni: Turunani sebagai fungsi Hiburan, sebagai fungsi komunikatif, sebagai fungsi yang berkaitan dengan norma sosial, dan turunani sebagai fungsi kesinambungan budaya.
\end{abstract}

Kata Kunci: Seni Pertunjukan, Bentuk

\section{PENDAHULUAN}

Gorontalo sebagai salah satu etnis yang ada di Indonesia, memiliki beragam kesenian tradisi yang merupakan sebuah identitas daerah tersebut, dan kesenian gorontalo juga memiliki karakteristik tertentu sepertihalnya daerah lain diwilayah nusantara. Dari keragaman kesenian yang tumbuh dan berkembang di tengah-tengah masyarakat gorontalo, salah satunya adalah kesenian turunani. Umumnya, bentuk kesenian turunani hampir seluruh wilayah gorontalo dapat dikenal, walaupun tidak semua daerah lagi yang melaksanakan kesenian tersebut dalam berbagai kegiatan masyarakat. Khususnya di Kecamatan Tapa, Desa Kramat, oleh masyarakat setempat memahami Turunani sebagai kesenian tradisi gorontalo yang masih ditemukan pada berbagai kegiatan masyarakat seperti: upacara adat pernikahan, aqiqah, maupun khitanan, dan lain sebagainya, yang secara kebentukan musiknya terdiri dari permainan pola-pola tabuhan rebana, dan lantunan syair-syair vokal. Mencermati kehadiran turunani yang begitu kompleks khususnya di Kecamatan Tapa, Desa Kramat, dapat diasumsikan bahwa kesenian tesebut hampir mewarnai berbagai kegiatan masyarakat dan tentunya memiliki kedudukan yang sangat penting bagi masyakat sebagai pemilik kebudayaan. Dan kehadiran kesenian tersebut tentu tidak lain bertujuan untuk menopang nilai-nilai kebudayaan masyarakat sebagai warisan leluhur yang perlu dilestarikan eksistensinya. 


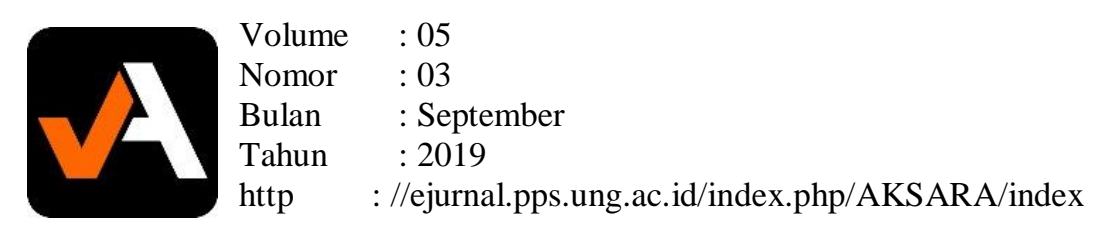

Seperti yang telah dikatakan di atas, bahwa kehadiran turunani oleh masyarakat Desa Kramat selalu disandingkan dengan berbagai fenomena kebudayaan. Hal yang menggelitik penulis bahwa mengacu pada observasi awal, oleh masyarakat setempat mengatakan bahwa, pertunjukan turunani secara kebentukannya pada setiap kegiatan sangat berbeda. Oleh sebab itu, persoalan yang muncul saat ini adalah apa yang membedakan kebentukan pertunjukan turunani tersebut dalam berbagai konteks kebudayaan masyarakat gorontalo? Aspek apa saja yang membedakan bentuk pertunjukan turunani yang dihadirkan dalam upacara adat pernikahan, aqiqah, maupun khitanan? Serta bagaimana struktur musikal turunani tersebut disetiap konteks pertunjukannya? Dari beberapa persoalan yang telah diungkapkan, tentunya hal inilah yang memotivasi penulis untuk mengkaji lebih jauh terkait dengan turunani sebagai salah satu kesenian tradisi gorontalo.

Mencermati persoalan di atas, terkait dengan kehadiran turunani dalam berbagai kegiatan masyarakat, tentu hal ini sangat disayangkan ketika warisan leluhur tersebut tidak lagi dijadikan sebagai suatu kekayaan akan tradisi gorontalo. Sebuah kenyataan yang tidak dapat dibendung belakangan ini adalah kekuatan modernisasi yang lahir di era-globalisasi seperti sekarang ini, dimana kecenderungan generasi muda sudah lebih memilih belajar musik gaya kebarat-baratan yang bersifat populer ketimbang belajar turunani. Dengan demikian, agar kesenian khususnya turunani di gorontalo tidak mengalami kepunahan, perlu adanya tindakan-tindakan inovatif seperti melakukan studi kebentukan, fungsi, maupun makna, terhadap turunani ditinjau dari struktur musikal dan konteks penyajiannya.

\section{KAJIAN PUSTAKA}

\section{Konsep Seni Pertunjukan Dalam Kebudayaan Masyarakat}

Seni pertunjukan merupakan suatu hasil kerjasama yang dilakukan secara kolektif antara seniman sebagai pelaku seni dengan pendukung-pendukung lainnya. Hal ini sebagaimana dipertegas Edi Sedyawati (1981), mengatakan bahwa "seni pertunjukukan pada pertamanya menyangkut suatu kerja kelompok yang membutuhkan hadirnya dua pihak, yakni penyaji, dan penerima" (Edi Sedyawati (1981:61).

Pada dasarnya, seni pertunjkan dalam kebudayaan masyarakat tidak terlepas dari aspek kebentukan yang berhubungan dengan aspek-aspek lainnya. Kata "Bentuk" menurut Smith (dalam Siluh Made Astini, 2007:173) bentuk didefinisikan sebagai hasil pernyataan berbagai macam elemen yang didapatkan melalui vitalitas estetis, sehingga hanya dalam pengertian itulah elemenelemen tersebut dihayati, dan proses pernyataan dimana bentuk dicapai sering disebut dengan istilah komposisi. Dilain pihak, oleh Djelantik (1999) mengemukakan lebih lanjut bahwa, kata bentuk, wujud, sturktur mengandung arti bahwa di dalam karya seni itu terdapat pengorganisasian, penataan, dan ada hubungan tertentu antara bagian-bagian yang tersusun. Selanjutnya oleh Sumandiyo Hadi (2012:7) mengemukakan bahwa, ketika seni pertunjukan disajikan atau dipertontonkan bagi para pengamat, maka selalu dihadapkan atas pilihan dua aspek keberadaan, yaitu "teks" yang bersifat kebentukan atau struktur luar (surface structure) yang dapat dilihat, didengar, dan aspek konteks tentang isi atau struktur dalam (deep structure) yang tidak nampak.

\section{Konsep Analisis Musik}

Dalam melakukan analisis musikal, tentu terlebih dahulu harus dipahami apa yang dimaksud dengan analisis. Dalam Kamus Ilmiah Populer (2009:16), analisa adalah penguraian suatu pokok atas berbagai bagiannya dan penelahan bagian itu sendiri serta hubungan antara bagian untuk

164 AKSARA Jurnal Ilmu Pendidikan Nonformal 


$\begin{array}{ll}\text { Volume } & : 05 \\ \text { Nomor } & : 03 \\ \text { Bulan } & : \text { September } \\ \text { Tahun } & : 2019 \\ \text { http } & : \text { //ejurnal.pps.ung.ac.id/index.php/AKSARA/index }\end{array}$

memperoleh pengertian yang tepat dan pemahaman arti keseluruhan. Dalam hal ini, analisis diartikan sebagai pengkajian suatu masalah terhadap suatu peristiwa sehingga dapat diketahui latar belakang dan duduk permasalahannya atau proses kejadiannya. Dan analisis musik yang dimaksud adalah menelaah dan menguraikan struktur musikal seperti pola ritme, meter, intensitas suara (keras lembutnya suara) dan lain sebagainya.

Dengan demikian, dalam konteks penelitian ini untuk menganalisis aspek musikal dalam hal ini lantunan vokal turunani dalam peristiwa kebudayaan masyarakat gorontalo, penulis mengacu pada teori yang dikemukakan oleh William P. Malm yang dikenal dengan teori weighted scale dan hal-hal yang harus diperhatikan dalam mendeskripsikan melodi, yaitu (1) tangga nada (scale), (2) nada dasar (pitch center), (3) wilayah nada (range), (4) jumlah nada (frequency of note), (5) jumlah interval, (6) pola kadensa (cadence patterns), (7) formula melodic (melody formula), dan (8) kontur (contour) (Malm dalam terjemahan Takari 1993: 13). Sedangkan permainan rebana dari segi ritmis, akan dideskripsikan secara keseluruhan dari awal hingga akhir permainannya. Agar pekerjaan ini dapat dilakukan, maka terlebih dahulu akan membuat notasi secara tertulis agar seluruh aspek musikalnya dapat diketahui dan akan mempermudah proses analisis selanjutnya.

Selain teori di atas, dalam rangka menelusuri konsep upacara adat peralihan yang didalamnya terdapat pertunjukan turunani, maka peneliti juga menggunakan konsep teori Van Gennep (dalam J. Van Baal,1988: 27) bahwa peralihan manusia dimulai sejak dari kandungan, kelahiran, perkawinan dan pemakaman/kematian yang pelaksanaannya selalu ditandai dengan tahap-tahap tertentu dalam ritus peralihan tersebut. Selanjutnya terkait dengan proses peralihan Van Gennep (dalam J. Van Baal, 1988:26) mempertegas bahwa peralihan dari satu kelompok (status) ke kelompok (status) yang lain berjalan menurut skema tertentu. Dan hal tersebut selalu ada tiga tahap dalam pelaksanaannya, yaitu tahap perpisahan dari keadaan yang semula, peralihan yang sebenaranya ke status yang baru, dan akhirnya diterimanya kembali dalam kelompok (status) yang baru. Dan tahap-tahap itu disertai dengan ritus, tahap yang pertama desertai "ritus perpisahan" tahap kedua disertai "ritus peralihan", dan tahap terakhir disertai "ritus penerimaan" dalam status yang baru.

Dengan demikian, mengacu dari teori di atas, maka dari beberapa upacara adat tradisi yang didalamnya terdapat pertunjukan turunani, seperti: Aqiqah, Khitanan, maupun pernikahan, dapat dikatakan bahwa hal ini termasuk dalam konteks peralihan manusia yang selalu ditandai dengan sebuah prosesi pada setiap tahapan-tahapan pelaksanaannya, sehingga dapat diklasifikasikan tahapan-tahapan tersebut menurut jalannya prosesi pada masing-masing peralihan.

\section{METODE PENELITIAN}

Pengumpulan data dalam penelitian ini dapat dilakukan melalui (1) observasi, yakni menelusuri secara berulang-ulang objek yang akan diteliti secara keseluruhan sehingga akan menemukan pehaman yang lebih detail dan akan ditemukan data primer dan data sekunder terhadap objek tersebut. (2) wawancara, merupakan proses komunikasi dua arah antara peneliti dengan informan yang dilakukan melalui wawancara mendalam (in-depth interview). Hal ini dilakukan, mengingat data-data terkait objek penelitian ini masih banyak tersimpan secara oral, sehingga perlu dilakukan pencatatan poin-poin penting dan perekaman agar selama proses wawancara tidak ada satu datapun yang terlewatkan. (3) Dokumentasi, baik audio, visual, maupun audio-visual.

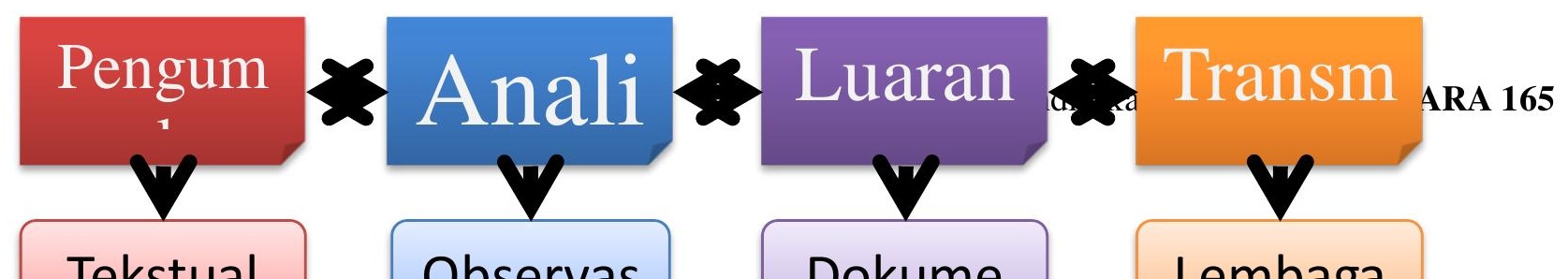




$\begin{array}{ll}\text { Volume } & : 05 \\ \text { Nomor } & : 03 \\ \text { Bulan } & : \text { September } \\ \text { Tahun } & : 2019 \\ \text { http } & : \text { //ejurnal.pps.ung.ac.id/index.php/AKSARA/index }\end{array}$

Bagan 1: Alir Penelitian Yang Akan Dilakukan

\section{HASIL PENELITIAN DAN PEMBAHASAN \\ Hasil Penelitian \\ Turunani Di Gorontalo}

Turunani merupakan istilah populer yang dikenal oleh masyarakat gorontalo, dan berasal dari kata "Taranama ya taranamu, ya taranuma" yang berarti syair yang dilagukan dengan cara berdendang dan terdiri dari kumpulan shalawat-shalawat yang berisi tentang sanjungan dan pujipujian kepada Nabi Muhamad SAW. Secara historis, kehadiran kesenian yang bernuansa islam di gorontalo, tidak terlepas dengan masuknya peradaban islam yang dibawa oleh Sultan Amai pada tahun 1525 di gorontalo. Dan hal tersebut juga sebagai wujud persyaratan yang harus dipenuhi atas pernikahan Sultan Amai dengan seorang putri Owutango, yang merupakan anak dari Raja Bonenato di Kerajaan Gomonjolo, Teluk Tomini, Palasa (Alim Niode dan Elnino, 2003:18-19).

Dalam upaya memperluas syiar islam di gorontalo yang dilakukan oleh Sultan Amai, lanjut (Alim Niode dan Elnino, 2003:19) mempertegas bahwa upaya-upaya tersebut dilakukan dengan cara memasuki seluruh lapisan masyarakat baik lembaga-lembaga pendidikan, hukum keluarga, seni dan budaya (yang disebutkan hanya salah satu kesenian yakni Tidi lo Polopalo), dan lain sebagainya. Dengan demikian, mengacu dari fenomena historis tersebut, maka dapat dikatakan bahwa masuknya pengaruh islam di gorontalo sangat mempengaruhi seluruh sendi-sendi kehidupan diberbagai kalangan masyarakat, termasuk di dalamnya adalah kesenian. Dalam arti bahwa, sejumlah tradisi yang ada di gorontalo secara otomatis menyesuaikan dengan nilai-nilai islam yang menjadi landasan hidup masyarakat, walaupun hal ini dilakukan secara perlahan dan juga tidak secara keseluruhan jenis-jenis kesenian tradisi di gorontalo menyesuaikan dengan nilainilai islam, sepertihalnya Dayango yang sampai saat ini masih tetap dilestarikan walaupun menurut beberapa kalangan mengatakan bahwa tidak sesuai dengan ajaran agama islam. Akan 


$\begin{array}{ll}\text { Volume } & : 05 \\ \text { Nomor } & : 03 \\ \text { Bulan } & : \text { September } \\ \text { Tahun } & : 2019 \\ \text { http } & : \text { //ejurnal.pps.ung.ac.id/index.php/AKSARA/index }\end{array}$

tetapi, perlu juga dipahami bahwa hal ini juga merupakan warisan leluhur masyarakat yang telah diwariskan secara turun-temurun.

Mengacu dari kondisi di atas, tentu kesenian gorontalo pada umumnya selalu mewarnai berbagai kehidupan masyarakat termasuk di dalamnya adalah musik. Hal ini sebagaimana dikatakan Alan P. Merriam (1964), bahwa kegunaan musik mencakup semua kebiasaan memakai musik di dalam masyarakat, baik sebagai suatu aktivitas yang berdiri sendiri maupun sebagai iringan aktivitas lain, (Merriam, 1964: 45). Dalam arti bahwa, musik dalam konteks kebudayaan bisa saja sebagai suatu kegiatan yang dilakukan di atas panggung, dan juga sebagai iringan dalam suatu kegiatan kebudayaan yang dihadirkan pada tempat-tempat tertantu sebagaimana konteks kegiatannya, seperti pada kegiatan upacara adat dan lain sebagainya.

Terkait dengan kehadiran Turunani di gorontalo, selain memiliki latar belakang historis yang cukup panjang, juga memiliki latar belakang kultur yang kuat sehingga sampai saat ini dapat diwariskan dari generasi ke generasi. Dan tentu hal ini tidak dapat dipungkiri kehadirannya sangat mewarnai berbagai kehidupan masyarakat, baik Turunani yang dihadirkan dalam bentuk upacara adat, maupun Turunani yang dihadirkan dalam kegiatan masyarakat yang bersifat profan/hiburan. Ditinjau dari segi kebentukan seninya, menurut bapak Yamin Husain mengatakan bahwa, Turunani memiliki unsur vokal yang dilantunkan dalam bentuk syair berbahasa arab, dan memiliki delapan bagian/jenis lantunan yang terdiri dari: (1) Al-Aqiqi, (2) Natahayirudaa/keselamatan besar, (3) Natahayirukiki/keselamatan kecil, (4) Suluta, (5) Jaraha Li Kalibi, (6) Sallu ala, (7) Jainati Jarati, (8) Hatamu. Dari ke delapan bagian lantunan Turunani, pada dasarnya secara keseluruhan menggunakan instrument/alat musik rebana yang dimainkan dengan cara ditabuh untuk mengiringi lantunan vokal tersebut (wawancara dengan bapak Yamin Husain, 20 Agustus 2015). Dan Untuk memahami Turunani dalam kebudayaan masyarakat gorontalo khususnya di desa kramat, tentunya tidak bisa dipisahkan dengan fenomena kebudayaan dimana kesenian tersebut dihadirkan, seperti: Turunani yang dihadirkan dalam upacara adat pernikahan, sunatan, pembeatan (untuk perempuan), maupun aqiqah/Gunting rambut.

Secara umum, upacara adat tradisional masyarakat gorontalo merupakan serangkaian kegiatan yang dilaksanakan baik dalam hal peralihan manusia, maupun kegiatan-kegiatn simbolik lainnya yang menyimpan berbagai makna filosofi yang terkandung di dalamnya. Sehingga, berbagai kegiatan upacara adat yang ada di gorontalo tentu tidak hadir begitu saja, melainkan memiliki latar belakang kultur yang kokoh di atas fondasi Adat Bersendikan Sarah, Sarah Bersendikan Qitabullah. Begitu pula ketika kesenian ditemukan dalam sebuah fenomena kebudayan, maka kesenian tersebut memiliki fungsi dan peran dalam kegiatan kebudayaan, sehingga hal tersebut tidak dapat terpisahkan anatara keduanya, melainkan saling mendukung dan melengkapi, guna mencapai tujuan yang diinginkan.

Dengan demikian, dari pengklasifikasian upacara adat tradisional gorontalo yang di dalamnya terdapat pertunjukan Turunani sebagaimana telah disebutkan di atas, maka dapat dikatakan bahwa Turunani memiliki bentuk dalam setiap pertunjukannya, dan untuk mengkaji kebentukan Turunani dalam upacara adat tradisional seperti: Upacara adat Aqiqah, Sunatan, pembeatan (untuk wanita), dan pernikahan, di gorontalo, maka terlebih dahulu harus diketahui bagaimana prosesi tata upacara adat yang dilaksanakan oleh masyarakat gorontalo umumnya, khususnya di Kecamatan Tapa, Kabupaten Bone Bolango.

\section{Prosesi Upacara Adat Tradisional Masyarakat Desa Kramat}




$\begin{array}{ll}\text { Volume } & : 05 \\ \text { Nomor } & : 03 \\ \text { Bulan } & : \text { September } \\ \text { Tahun } & : 2019 \\ \text { http } & : \text { //ejurnal.pps.ung.ac.id/index.php/AKSARA/index }\end{array}$

Fenomena prosesi upacara adat tradisional gorontalo hampir seluruh wilayah Kabupaten/Kota ditemukan memiliki kesamaan, walaupun dibeberapa daerah sudah ada yang mulai meninggalkan beberapa tahapan atau prosesi dalam upacara adat tradisi tersebut. Akan tetapi, hal ini walaupun beberapa tahapan atau prosesi telah dihilangkan, substansi prosesi upacara adat tetap mengacu pada kesepakatan para tokoh adat yang menjadi acuan secara bersama, dan telah diwariskan secara turun temurun, dari generasi kegenerasi. Meskipun demikian, dalam penelitian ini peneliti tetap mengacu dari salah satu desa yang sampai saat ini masih melaksanakan kompleksitas tata upacara adat tradisi yakni di Desa Kramat, Kecamatan Tapa, Kabupaten Bone Bolango, dan dibatasi pada upacara adat peralihan manusia yang didalamnya terdapat sebuah pertunjukan seni yakni turunani. Adapun upacara adat tradisi yang di dalamnya terdapat pertunjukan Turunani, yakni upacara adat Aqiqah, Sunatan/khitanan, Pembeatan (untuk wanita), dan Pernikahan.

\section{Pembahasan}

Dari deskripsi hasil penelitian di atas, terkait dengan alasan-alasan kehadiran Turunani diberbagai upacara adat peralihan masyarakat Desa Kramat, Kecamatan Tapa, maka terlebih dahulu perlu memahami bagaimana konsep peralihan masyarakat yang dilaksanakan secara utuh sesuai dengan tahap-tahap pelaksanaannya, sehingga akan memberikan dasar pijakan dalam menentukan berbagai alasan logis atas kehadiran kesenian tersebut. Dan untuk memahami hal tersebut, maka mengacu dari konsep peralihan sebagaimana yang dikatakan oleh Van Gennep (dalam J. Van Baal, 1988:26) yang mengatakan bahwa peralihan dari satu kelompok (status) ke kelompok (status) yang lain berjalan menurut skema tertentu. Dan hal tersebut selalu ada tiga tahap dalam pelaksanaannya, yaitu tahap perpisahan dari keadaan yang semula, peralihan yang sebenaranya ke status yang baru, dan akhirnya diterimanya kembali dalam kelompok (status) yang baru.

Dari hasil penelitian di atas, nampak bahwa turunani yang dihadirkan diberbagai upacara adat tradisi pada masyarakat Desa Kramat, Kecamatan Tapa, selalu dihadirkan sebelum memasuki tahap-tahap liminal. Hal ini dapat diketahui ketika mencermati deskripsi prosesi upacara adat yang telah dideskripsikan di atas, sangat jelas ada beberapa rangkaian prosesi sebelum pertunjukan turunani dilaksanakan. Khususnya turunani yang dihadirkan dalam upacara adat Aqiqah, kehadiran turunani disini ditemukan pada tahapan sesudah sesudah pemotongan kambing, tepatnya pada pagi hari sebelum memasuki prosesi mohunthingo. Kalau diklasifikasikan menurut tahapan pelaksanaannya, maka dapat dikatakan bahwa prosesi pemotongan kambing berada ada pra-peralihan termasuk turunani didalamnya, dan turunani disini berada pada puncak praperalihan, dengan lantunan syair Al-Aqiqi. Sehinga, dapat dikatakan bahwa pada tahap ini, sang anak yang akan di aqiqah sedang dipersiapkan untuk memasuki pada tahap peralihan yang sebenarnya. Dan lantunan salawatan syair-syair turunani terus dikumandangkan sampai tiba saatnya untuk memasuki tahap peralihan yang sebenarnya, ditandai dengan prosesi gunting rambut yang diiringi dengan lantunan barzanji tepatnya pada bagian asraka. Dalam proses peralihan ini, tentunya tidak terlepas dari harapan-harapan kedua orang tua sang anak, seperti: anak tersebut selalu diberikan kesehatan, kemudahan rejeki, selalu berbakti kepada ke dua orang tua, memiliki ahlak yang baik sebagaimana yang telah dicontohkan oleh Nabi Muhammad SAW sebagai suri teladan oleh umat manusia, dan lain sebagainya.

168 AKSARA Jurnal Ilmu Pendidikan Nonformal 


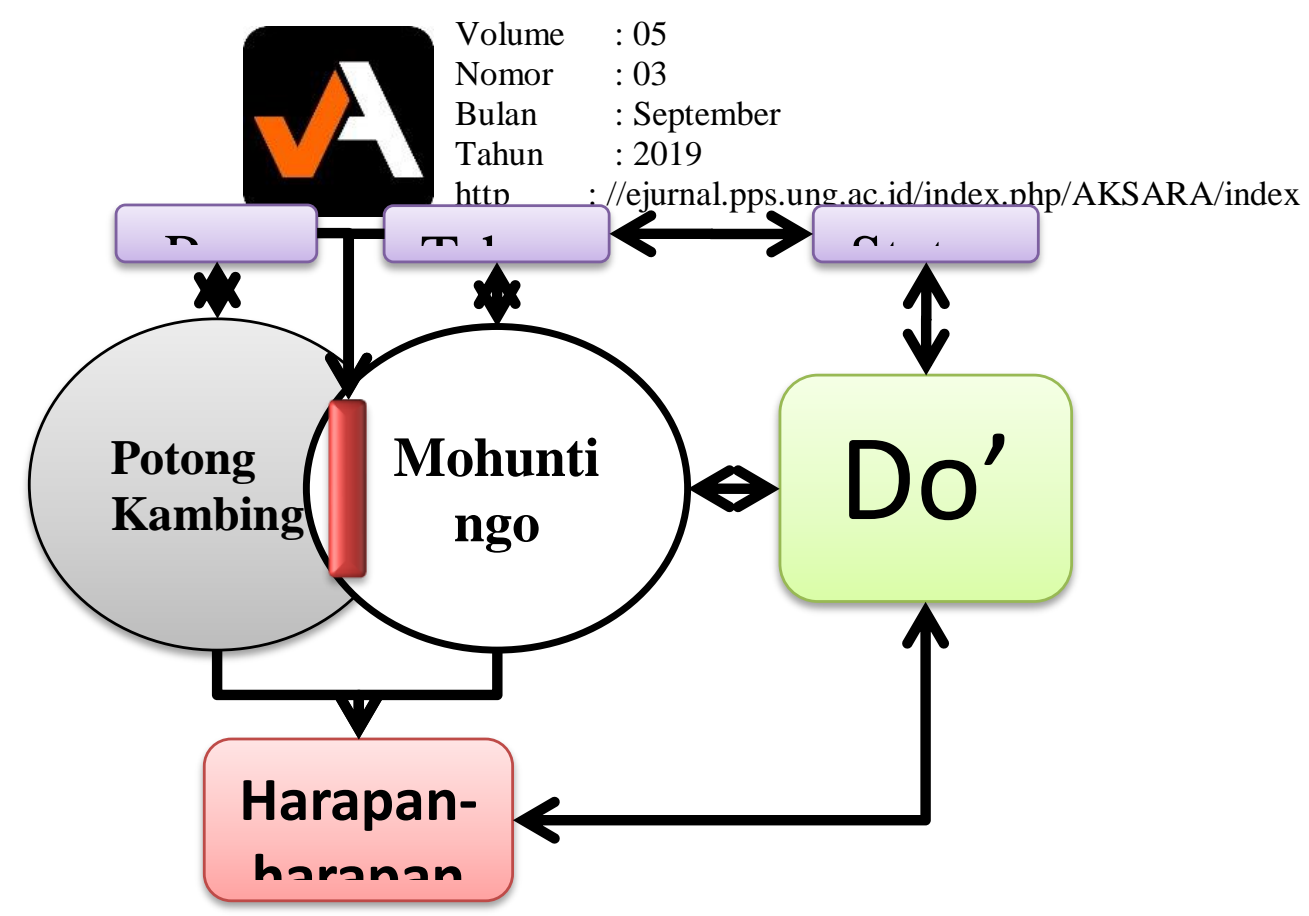

Bagan. 8: Turunani Dalam Upacara Adat Mohuntingo

Selain turunani yang dihadirkan dalam prosesi Aqiqah, turunani juga dihadirkan dalam upacara adat khitanan, sebagaimana telah dideskripsikan di atas, bahwa prosesi khitanan terbagai atas upacara adat Mongubingo dan upacara adat Moluna. Khususnya pada upacara adat Mongubingo yang dilaksanakan menururt klasifikasi tahapan-tahapan pelaksanaannya, maka praperalihan dalam kegiatan tersebut ditandai dengan pelaksanaan Mopolihu Lo Limu atau mandi air ramuan/mandi uap, mongadi salawati yang biasanya dilaksanakan oleh imam/hatibi atau oleh siapa saja yang dipercayakan, dan setelah itu dilanjutkan dengan memandikan sang anak dengan ramuan yang sudah disiapkan. Setelah semua prosesi ini dilaksanakan, selanjutnya mempersiapkan sang anak untuk dikhitan/disunat dengan menggunakan busana adat/takowa. Selama persiapan, disinilah pertunjukan Turunani dihadirkan dengan melantunkan syair nahatairukiki yang berarti keselamatan kecil, sambil menunggu para undangan yang datang menghadiri prosesi tersebut. Sehingga, lantunan syair-syair salawatan terus dikumandangkan, karena anak tersebut telah tiba saatnya untuk dialihkan dari status lamanya ke status barunya. Dan setelah prosesi khitanan ini, maka sang anak diterima kembali ke dalam masyarakat dengan status yang baru. Selain prosesi Mongubingo yang didalamnya terdapat pertunjunkan turunani, dalam upacara adat moluna juga ditemukan kehadiran turunani yang nampak juga kehadirannya berada pada puncak pra-peralihan, untuk memasuki masa peralihan yang sebenarnya, dan hal ini ditandai dengan pelaksanaan prosesi mopolihu lo limu/mandi uap, setelah itu dilanjutkan dengan pertunjukan turunani tepatnya pada saat sang anak mengenakan pakean adat sambil menunggu para tamu yang diundang. Setelah para tamu telah hadir, turunani dihentikan, sang anak akan disiapkan untuk di be,at dan setelah itu dilanjutkan dengan khitanan sebagai peralihan yang sebenarnya ke status yang baru sehingga anak tersebut perlu diberikan penguatan melalui lantunan shalawat-shalawat dan puji-pujian kepada Nabi Muhamad SAW.

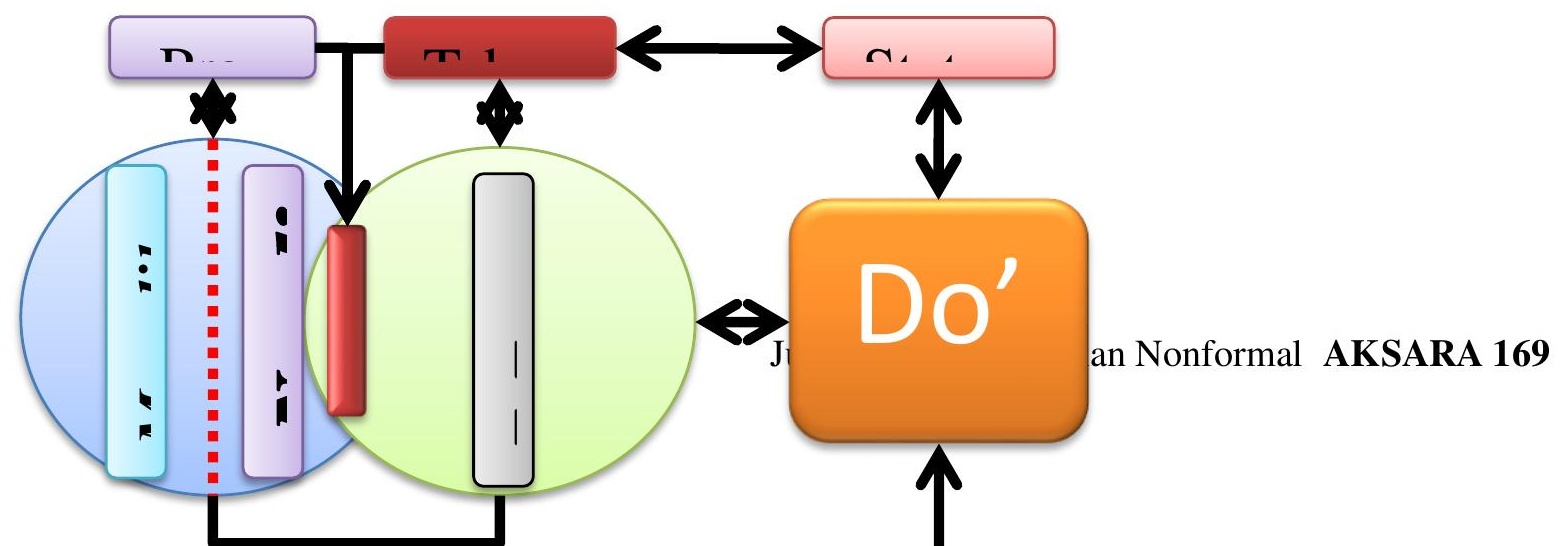




$\begin{array}{ll}\text { Volume } & : 05 \\ \text { Nomor } & : 03 \\ \text { Bulan } & : \text { September } \\ \text { Tahun } & : 2019 \\ \text { http } & : \text { //ejurnal.pps.ung.ac.id/index.php/AKSARA/index }\end{array}$

Bagan. 9: Turunani Dalam Upacara Adat Mongubingo

\section{PENUTUP}

Dari hasil pembahasan di atas, maka terkait dengan bentuk turunani yang dihadirkan dalam berbagai upacara adat peralihan masyarakat Desa Kramat, Kecamatan Tapa, dapat disimpulkan bahwa kehadirannya tidak dapat dilepaskan antara turunani dengan konteks peristiwa kebudayaan, sehingga secara kebentukan pertunjukannya memiliki struktur yang dapat menjaring seluruh elemen-elemen pendukung, guna pencapaian tujuan tertentu. Dalam arti bahwa, ketika turunani dihadirkan dalam uapcara adat Aqiqah, maka elemen-elemen di dalamnya saling berhubungan seperti: antara pemotongan kambing dan proses mohuntingo yang di dalamnya terdapat pertunjukan turunani dengan lantunan syair-syair berbentuk shalawat dan puji-pjian kepada Nabi Muhammad SAW, agar anak tersebut dalam menjalani kehidupannya selalu diberikan kesehatan, perilaku seperti yang telah dicontohkan Nabi Muhammad SAW, memiliki moralitas yang baik, dan lain sebagainya.

\section{DAFTAR PUSTAKA}

Astini Siluh Made, Utina Usrek Tani, 2007, Tari Pendet Sebagai Tari Balih Balihan. Semarang: Jurnal Harmonia Vol VIII.

Baal Van J. 1988: Sejarah Pertumbuhan Teori Antropologi Budaya, Jakarta: PT

Botutihe Medi, dan Daulima Parha 2003, Tata Upacara Adat Gorontalo, Hasil

Gramedia.

Djelantik 1999, Estetika Sebuah Pengantar, Bandung : Masyarakat Seni Pertunjukan Indonesia

Hadi Sumandiyo.Y, 2012: Seni Pertunjukan dan Masyarakat Penonton. Yogyakarta:

BP ISI Yogyakarta

Malm, William P. 1977. Music Cultures of the Pacific, Near East, and Asia. New Jersey,Englewood Cliffs: Prentice Hall.

Meriam, Allan. P. 1964. The Antropologi Of Music Chicago. North Western University Press. 